\title{
ЛІНГВІСТИЧНІ ЕКСПЕРИМЕНТИ Т. ШЕВЧЕНКА, АБО ЗАГАДКА, ЧОМУ РОСІЙСЬКА МОВА ОБРАНА МОВОЮ ПИСЬМЕННИЦЬКОГО ЩОДЕННИКА (до 200-ліття від дня народження письменника)
}

\author{
ТЕТЯНА КОСМЕДА \\ Університет імені Адама Міцкевича, Познань - Польща \\ LINGWISTYCZNE EKSPERYMENTY T. SZEWCZENKI \\ ALBO ZAGADKA, DLACZEGO \\ JEZZYK ROSYJSKI ZOSTAŁ WYBRANY \\ NA JĘZYK DZIENNIKA LITERACKIEGO \\ (z okazji 200 rocznicy urodzin pisarza) \\ TETIANA KOSMEDA \\ Uniwersytet im. Adama Mickiewicza, Poznań — Polska
}

STRESZCZENIE. W artykule omówiono przyczyny pisania przez T. Szewczenkę

dziennika po rosyjsku. Przedstawiono opinie badaczy i zaprezentowano przemyślenia autorki na temat powodów takiej praktyki piśmienniczej. Wśród nich wymieniono: nieukształtowany w tamtych czasach styl prozy ukraińskiej, na co istotny wpływ miały rozporządzenia carskie zabraniające posługiwania się językiem ukraińskim; chęć kamuflażu, gra, zwłaszcza słowna, eksperymenty lingwistyczne związane z psychotypem T. Szewczenki, jego ironicznym charakterem, jaki przejawia się w umiejętności wykorzystania humoru i żartów; przebywanie w środowisku rosyjskojęzycznym, pragnienie doskonałego opanowania języka rosyjskiego, umożliwiającego rozmowy z przyjaciółmi rosyjskojęzycznymi (Rosjanami i Ukraińcami), utrzymywanie kontaktów z działaczami kultury w Rosji; posiadanie obywatelstwa Imperium Rosyjskiego i inne. Ważny jest również poziom władania językiem rosyjskim. Porównano rosyjskojęzyczną praktykę językową Kobziarza z praktyką literacką M. Gogola.

\section{T. SHEVCHENKO'S LINGUISTIC EXPERIMENTS, OR PUZZLE WHY RUSSIAN IS CHOSEN AS THE LANGUAGE OF THE WRITER'S DIARY}

(to the writer's $200^{\text {th }}$ anniversary)

\section{TETYANA KOSMEDA \\ A. Mitskevych University, Poznan - Poland}

ABSTRACT. The author of the article finds out reasons why T. Shevchenko wrote his diary in Russian. The opinions of scientists and authorial reflections are generalized for the representation of reasons that explain the underlined problem. The authour describes such reasons as: the absence of Ukrainian prose style because of tsar's prohibitions on the use of Ukrainian; T. Shevchenko's disposition to game (including language game), linguistic experiment associated with Shevchenko's psychotype, his ironic nature, capacity for humor, jokes, game; stay in Russian environment, the desire to speak Russian perfectly (to communicate with Russian-speaking friends, artists, etc.); citizenship of the Russian empire. T. Kosmeda compares Kobzar's Russian-language lingual activity with M. Gogol's literary activity. 
ому великий Кобзар свій інтимний твір писав російською мовою, а не рідною українською? Зрештою, чому взагалі геній української нації здійснював лінгвокреативну діяльність російською мовою, адже відомо, що, крім щоденника, російською він написав низку творів: автобіографію та одинадцять повістей - Сліпа, Близнюки, Художник, Капітанша, Прогулянка із задоволенням і не без моралі, Безталанний, Музикант, Княгиня, Нещзасний? Як відомо, були спроби писати російською й поезію. Свої листи Т. Шевченко також писав переважно мовою російською. Уважаємо, що однієї причини не існує. Узагальнюючи напрацьоване й викладаючи власні міркування, спробуємо об'єднати ці причини в систему'.

3 приводу виокремленої проблеми озвучимо таку думку Б. Рубчака: „На хвилину повернуся до російської мови „Журналу”: можливо, що найголовніша 3 причин переходу на російську мову в „Журналі” — це не тільки наблизити, але, найголовніше, віддалити свої “пітерські”, “імперські” переживання, разом із переживаннями в Новопетровській кріпості (які, дарма що начебто такі відмінні, мають той самий корінь), закодовуючи їх у іншість чужої мови, а також віддалити своє найближче оточення в іншість мови цього оточення" 2 . Можливо, це такий собі лінгвістичний експеримент письменника, лицедійство, мовна гра, на що звертає нашу увагу, власне, Б. Рубчак, порівн.: “Як би там не було, немає сумніву, що „Журнал” породила приємність від писання, втіха писання. I ця гра помітна всюди. „Журнал” читається сьогодні не як щоденник (або, точніше, не тільки як щоденник), а якась експериментальна, “постмодерністична" повість, що в ній, особливо в іiі четвертій частині, коли героєві загрожує остаточне розсіяння, включений і “піджанр” щоденника. У тексті бо бачимо власне віддзеркалення тексту — розмови про писання взагалі, а особливо про писання цього тексту, - бачимо уважно гармонійовані найрізноманітніші стилі, раптові удари протилежних настроїв, багатство й неспівмірність тематичного матеріалу, i, щонайголовніше, членування героя на “маски”, “персони”, “ролі”, які мусять (і це - найтрудніше завдання такого романіста-експериментатора) кружляти довкола якогось невидимого центру, щоб не розпастися на цілком автономні персонажі. Про різні аспекти “пророчості" в Кобзарі сказано багато, хоч майже нічого не сказано про “пророчість" цього тексту щодо експериментальної української поезії. А „Журнал” може бути теж (у цьому відношенні) “пророчий”, стаючи передвісником майбутньої української прози. Не всі ми, звичайно, хочемо так прочитати Шевченків „Журнал”. Але всі ми мусимо визнати, що цей текст — високовартісний літературний твір, який творить своєрідну пару 3 домежно звільненою структурою Кобзаря"з .

Про окреслене розмірковують досвідчені й молоді вчені, письменники, літературні критики різних часових періодів упродовж XIX - XXI ст., дається різна оцінка цьому факту, по-різному його потрактовують, до речі, розглядають і сам факт ступеня знання українським письменником російської мови. Серед дослідників російськомовної спадщини Т. Шевченка чи тих, хто потрактовував російськомовну креативність поета, С. Аксаков, О. Афанасьєв-Чужбинський, Ю. Барабаш, Г. Біловус, Л. Грабовський, Н. Демчук, О. Забужко, А. Козачков-

${ }^{1}$ Див. про це: Т. А. Космеда, Ego i Alter Ego Taраса Шевченка в комунікативному просторі щоденникового дискурсу, Дрогобич 2012.

2 Б. Рубчак, Живописаний Шевченко (,,Журнал” як текст), [в:] Світи Тараса Шевченка, Збірник статей до 175-річчя 3 дня народж. поета, ЗНТШ, Філологічна секція, т. 214, Нью-Йорк, 1989 , с. $85-86$.

${ }^{3}$ Там само, с. 88. 
ський, О. Кониський, П. Куліш, О. Литвинникова, Ю. Луцький, В. Мовчанюк, Є. Нахлік, Б. Рубчак, В. Русанівський, М. Чалий та ін.

Причиною, що змусила Тараса Шевченка писати прозу, навіть щоденник, російською мовою, В. Русанівський уважає, як і Б. Рубчак, те, що письменник “був прекрасним стилістом, а стиль української мемуарно-епістолярної літератури на той час був ще не вироблений"4, що й змусило його звернутися до мови російської, для того, щоб удосконалюватися, вправлятися.

Зазначену проблему глибоко, як видається, аналізував і О. Ткаченко, якому належить досить удалий термін щодо окреслення національної спільноти, яка недостатньо володіє національною мовою, зокрема це — "неповнота" нації. Названий учений зауважив, що “неповнота" української нації послідовно відображена в художній літературі, діяльності письменників, насамперед перекладачів. Учений наголошує, що ,українська література початку і навіть середини XIX-го століття відповідних мовних ресурсів ще не мала, а тому й не дивина, що свою прозу, навіть найінтимнішу (щоденник), Т. Шевченко писав російською мовою. Свою складну прозу, в тім числі і з українськими сюжетами, М. Гоголь, відомий своїми недвозначними українськими симпатіями, мусив також писати російською мовою, бо тодішньої української мови на складні прозові твори ще не вистачало"5. Мову прозових творів письменників Східної України О. Ткаченко називає „(напів)мертвою, перекладеною з російської”6. „Живою” він уважає лише мову письменників західної України, надаючи особливу оцінку роману I. Вільде Сестри Річинські. До речі, нагадаємо, що й I. Франко чимало прозових творів писав польською мовою, наголошуючи, що стиль художньої прози польської мови набагато розвиненіший, ніж мови української7.

Інша думка свідчить, що Т. Шевченко на засланні писав російською тому, що його опікуни, зокрема Іраклій Усков - комендант Новопетровського укріплення - виробляли клопотання щодо отримання для нього дозволу писати хоч би російською під відповідним наглядом. Але шевченкознавці вважають, що це легенда. „Навіть якщо таке клопотання було, то воно не передувало поетовим спробам писати російськомовну прозу, а лише виявляло намагання коменданта легалізувати цей творчий процес, що почався ще наприкінці 1852 р.".

Письменник знав не лише російську мову, але й російську літературу, культуру, насамперед фольклор, історію, що знову-таки засвідчують записи щоденника. Власне про все російське, очевидно, письменнику було зручніше писати російською мовою за умови факту доброго володіння нею.

Нагадаємо також, що почав писати щоденник Тарас Григорович у період свого життя, коли він вже десять років перебував у засланні — російськомовному оточенні: його повсякденне спілкування було російськомовним, він омовлював концептуальну картину світу росіян; на той момент письменник усвідомив концепти російської культури. Його світобачення, світосприйняття й світорозуміння було налаштовано на російську дійсність, зокрема й повертаючись

${ }^{4}$ Див.: В. М. Русанівський, Літопис творчості і боротьби, [в:] „Радянське літературознавство", 1986, № 9, с. 36 .

${ }^{5}$ О. Ткаченко, Проблеми захисту мов і мовного відродження, [в:] Мова і мовознавство в духовному жстті суспільства, Київ 2007, с. 113.

${ }^{6}$ Там само, с. 114.

7 Див. про це: Т. А. Космеда, Комунікативна компетенція Івана Франка: міжкультурні, інтерперсональні, риторичні виміри, Львів 2006. c. 280

${ }^{8}$ C. Нахлік, Доля - Los - Cудьба: Шевченко і польські та російські романтики, Львів 2003, 
у Петербург по Волзі, Т. Шевченко відвідував російські міста, продовжуючи знайомитися з російськими реаліями, насамперед культурою.

На думку О. Литвинникової ${ }^{9}$, свій щоденник Т. Шевченко писав російською тому, що призначав його не для всіх, а лише для своїх друзів, які переважно не знали української мови, оскільки належали до петербурзького бомонду, де українська мова, зрозуміло, не функціювала, оскільки навіть значна більшість тих українців, які на той час перебували в Петербурзі, користувалася навіть у побуті мовою російською.

Цю думку раніше висловлював і Б. Рубчак, зауважуючи, що одна 3 можливих причин того, що Журнал написаний російською - це ті знайомі й незнайомі „искренние друзья”. Передбачуваний читач Журналу тільки подекуди сходився з уже дійсними читачами шевченкової української поезії. „Ми ж знаємо, що деякі з цих останніх дуже дорікали Шевченкові (і нарікали на нього) за мову цього „інтимного” тексту. А коли ми вже при мові „Журналу”, то неможливо не погодитися 3 тими дослідниками, які твердять, що Шевченкові було природніше писати свій щоденник російською мовою, бо він жив у чужому середовищі, де урядовою й товариською мовою була мова російська. Висловлювати нею думки стало для нього річчю звичайною. Враховуючи цю біографічну умову, — пише Б. Рубчак, — я все-таки на вибір мови російської вбачаю й глибинні причини: я думаю, що російську мову вибрало не тільки біографічне "я", але й те, яке було збудоване для читача. Шевченко вибрав для „Журналу” російську мову для того, щоб прийняти російськомовну (що ні в якому разі не рівнозначне 3 російською) персону або маску. Особливі завдання, себто особливий читач, диктували, щоб така маска діаметрально протиставлялася масці українськомовній, що іiі зустрічаємо особливо часто в листах"10. Умовний термін “українськомовна маска” окреслює мовне втілення чогось, що тоді малося за запорозький дух — дуже розраховану стилізацію якоїсь такої мовної розпатланості, розв'язності, і при тому майже барокової декоративності ${ }^{11}$.

Відомо, що Т. Шевченко передбачав принаймні двох справжніх читачів свого щоденника, про що й писав у Журналі, - Михайла Лазаревського і Семена Гулака-Артемовським. 12 липня 1858 р. він і справді подарував рукопис щоденника М. Лазаревському з нагоди його іменин. М. Лазаревський оправив рукопис у сап'ян жовтуватого кольору з витисненими рамками.

Науковці, як зауважувалося, ставлять питання й про ступінь володіння Т. Шевченком російською мовою, наголошуючи, що він був невисокий, тобто мовна й комунікативна компетенції Т. Шевченка як російської мовної особистості оцінювалися посередньо. Але $\epsilon$ й інші твердження, де наголошується на досить високому рівні його російської мовної і комунікативної компетенціiі. Безперечно, оцінки сучасників Т. Шевченка щодо ступеню його володіння російською мовою є суб'єктивними, оскільки й самі оцінювачі, якщо належали до українських мовних особистостей, то могли досконало не знати російської, а тому й оцінка їхня була недостовірною, а ті оцінювачі, російська мова яких була для них рідною, могли характеризувати мовну компетенцію Тараса Григоровича щодо російської мови й негативно чи, м’яко кажучи, не дуже ви-

9 Див.: О. Литвинникова, Устойчивые словесные комплексы в „,Дневнике” Т. Г. Шевченко (Нижегородский период), [в:] Слово. Текст. Фраза, Сборник статей к 60-летию проф. М. А. Алексеенко, Москва 2002, с. 245.

${ }^{10}$ Б. Рубчак, зазн. джерело, с. 68.

11 Див. про це: Забужко О., Шевченків міф України. Спроба філософського аналізу, Київ $2001,160 \mathrm{c}$. 
соко. Суб'єктивність такої оцінки можна пояснювати низкою причин. Але ж письменник здійснював російською мовою лінгвокреативну діяльність у писемній формі. Вже сам цей факт засвідчує щонайменше належний рівень мовної компетенції в проекції на російську мову, а також компетенції комунікативної, культурологічної, емоційної ${ }^{12}$.

До речі, сам Т. Шевченко критично оцінює свої знання російської мови, зокрема стосовно вправності писати поезію він зауважував у щоденнику від 19 липня 1957 р.: „Жаль, что я плохо владею русским стихом...”. Але він висловлює наміри й надалі писати російською — „... эту оригинальную поэму [,, Сатрап и Дервиш”] нужно непременно написать по-русски”. Робимо висновки, що письменник був наполегливим і прагнув удосконалення російської мовної і комунікативної компетенції, тим паче, що мав підстави думати: „Боюся, как бы мне не сделаться модной фигурой в Питере. А на то похоже..." (таким є запис у щоденнику від 30 березня 1858 р.).

Є. Нахлік як автор фундаментальній монографії Доля - Los - Cyдьба: Шевченко і польські та російські романтики (2003) торкається питання бікультурності Шевченкового Еgo, висловлює свої міркування щодо його російськомовної спадщини. Цій проблемі присвячено зокрема невеликий підрозділ його монографії Мовно-культурне, політичне й геоетнічне роздвоєння. Проте, як видається, цей підрозділ містить дещо суперечливі думки, що зумовлено суперечливістю й неможливістю однозначної трактовки й самого дослідницького матеріалу ${ }^{13}$.

Частково тогочасна літературна критика, частково деякі друзі й товариші Т. Шевченка, як зауважувалося, високо не поціновували його російськомовних творів, докоряли йому в тому, що він пише російською. Про це є чимало свідчень. Є. Нахлик наводить відповідні откровення Кобзаря й стверджує, що Т. Шевченко „поступово переконувався у відсутності в нього мовно-версифікаційної можливості для цього - через недосконале володіння російською мовою та російським віршем. На його прозріння у цьому плані позначилися, очевидно, аж надто стримані відгуки російської преси..." ${ }^{14}$. Проте ми наводили й думку Т. Шевченка, репрезентовану в його щоденнику, що він таки планує писати російською.

Як видається, не можна бути таким категоричним в оцінці ступеня володіння Кобзарем російською мовою. Те, що його російськомовні поетичні твори не користувалися належною популярністю, оцінювалися не надто високо й не відіграли такого великого значення для становленні російської літератури, культури, як його поетична збірка Кобзар для української, насамперед пояснюється не тим чи тим рівнем володіння російською чи українською мовами, відповідними мовною й комунікативною компетенціями, а цілком іншим - синергетикою рідної мови, розумінням національного поетичного коду, наявністю широкого інтертекстуального банку на базі українського фольклору, статусом українського національного поета.

Не надто високий ступінь володіння російською мовою, якщо так його оцінювати, безперечно, зумовлений відсутністю належної освіти, але й рідну мову Т. Шевченко не вивчав у ліцеях, гімназіях, університетах, утім, став їі творцем.

До речі, Є. Нахлік, власне, також зауважує, що „своє вимушене звернення як письменника до російської мови Шевченко-засланець хотів зробити природним, але не зумів - на перешкоді стали закони психології творчості, нероз-

\footnotetext{
12 Див. про це: Т. А. Космеда, Ego i Alter Ego Tapaca Шевченка...

${ }^{13}$ С. Нахлік, зазн. джерело, с. 276-292.

${ }^{14}$ Там само, с. 277.
} 
ривний зв'язок художнього мислення з рідною мовою..."15. Аналіз щоденникової діяльності Тараса Шевченка з боку мовознавців і літературознавців, утім, не дає підстав так стверджувати. Інша річ, якщо порівнювати спадок Кобзаря, що репрезентований рідною мовою, то, безперечно, якість російськомовного доробку дещо нижча. Але ж це закономірно.

Не погоджуємося й з іншою тезою С. Нахліка, що, як видається, є надто сміливою гіпотезою, яка дещо спрощено омовлює ситуацію стовно того, що „Шевченко сам був не проти того, щоб піти дорогою Гоголя принаймні наполовину - стати двомовним українсько-російським письменником (російськомовні поеми, драми, повісті, щоденник). Мав честолюбний намір зайняти повноправне місце і в російському літературному процесі... Проте недостатнє володіння російською мовою та віршовою технікою, новітньою поетикою, розвинутою в російській прозі, не дало йому змоги це зробити"16. Зазначений вислів закреслює наявність у генія української нації справжніх патріотичних почуттів, національної ідеї, що послідовно й багатогранно виражена в Кобзарi. Тарас Шевченко не роздвоювався: він просто жив у відповідному суспільстві й творив у відповідних умовах. Не треба забувати, до речі, що як би там не було, але він був громадянином Російської імперії.

Як видається, засуджуючи Т. Шевченка, ми засуджуємо себе, діяльність нації, онтологія й розвиток якої здійснювався в кабальних умовах. Не можна так себе шмагати за реальне історичне минуле, шмагати свою національну гідність. Ситуація не така однозначна, про що вже йшлося. До речі, Є. Нахлік через кілька сторінок після наведених вище слів пише, що „Шевченко... узявся за створення чужомовних (російських) повістей під час свого поетичного мовчання, але писав їх не тільки ради кар'єри російськомовного письменника, а й з внутрішньої потреби, і хоча вони нерівноцінні за художньою довершеністю і стоять за мистецьким рівнем значно нижче від його поезії (з художнього боку їх досить низько оцінили С. Аксаков та П. Куліш, а редакція „Русского вестника” 1858 р. відмовилася друкувати „Прогулку с удовольствием и не без морали"), усе-таки відзначаються і певними художніми здобутками, зокрема, в царині психологічного аналізу"17. Отже, все-таки російськомовна спадщина Тараса Шевченка має цінність.

Є. Нахлік має рацію щодо оцінки Шевченка-художника, хоч і робить це, як видається, в досить різкій, категоричній формі, навіть вступаючи в суперечку із собою, некоректно порівнюючи діяльність Шевченка-художника із літературною діяльністю М. Гоголя, хоч остаточні його висновки є об'єктивними: „... чи шлях Шевченка-художника, якому Рада Імперської Санкт-петербурзької академії мистецтв ухвалила надати звання академіка гравірування (1860р.), не подібний до шляху Гоголя-письменника?! Бо ж малярська спадщина Шевченка, що починала розвиватися в руслі петербурзької академічної школи, $\epsilon$ явищем і російського, й українського живопису. Російська імперська культура прийняла і визнала Шевченка-маляра, так, як перед тим визнала Гоголя російськомовного письменника. Відмінність між ними в цьому випадку в тому, що Гоголь як митець слова послуговувався мовою, яка завжди є національною, тому дихотомія рідного й чужого тут проступає явно й виразно, а Шевченко як художник використовував кольори, що мають інтернаціональний харак-

\footnotetext{
15 Там само, с. 280.

${ }^{16}$ Там само, с. 277.

17 Там само, с. 280.
} 
тер, тим-то його участь у російському малярському процесі менш очевидна, внаслідок чого сприймається співвітчизниками не так вразливо, як розбудова Гоголем російської літератури. Звичайно, Шевченко відображав на малюнках й українські реалії та виражав інтернаціональними барвами світосприйняття українця, але це робив і Гоголь в „українських повістях”, проте російською мовою (хоч і з численними українізмами). Та все-таки, на відміну від Гоголя, Шевченко, навіть зближуючи українців і росіян в одну „нашу национальность” $(\mathrm{V}, 33)$, чітко ідентифікував свою національну свідомість з українською, а не також із російською, та й навіть не із загальноруською. Гоголь же ішов через культурну ідентифікацію з Росією до національної ідентифікації з нею (принаймні наполовину), тобто від культурного зросійщення до зросійщення національного"18.

Л. Мацько також розмірковує про те, яким же було ставлення Т. Шевченка до рідної мови, української мови як мови українського народу і як він ставився до тих, хто від неї відрікався. 3 їі висновками не можна не погодитися, оскільки вони спираються на висловлювання самого Т. Шевченка і міркування інших авторитетних дослідників. Т. Шевченко розрізняв малоросійське й справжнє українське, зокрема й у ставленні до мови. На думку Л. Мацько, особливо це виокремлюється за умови порівняння двох талантів України, передусім їхнього ставлення до рідної мови. Маємо на увазі М. Гоголя і Т. Шевченка: першого слід кваліфікувати як малороса, оскільки для нього не існувала проблема репрезентації рідної української мови. Т. Шевченко - абсолютна протилежність.

Якщо М. Гоголь був переконаний, що мусить писати виключно російською мовою, прославляючи й популяризуючи культуру України, ïi історію і традиції, то Т. Шевченко вивчив російську мову, навіть писав нею, але не забув рідної української, а навпаки, прославив її своїм талантом і творчістю. М. Гоголь, очевидно, не вірив у майбутнє українців як самостійної нації із самостійною національною українською мовою, а Т. Шевченко не лише вірив, але й максимально спричинився до того, щоб саме так і сталося. Він не до кінця розумів, чому М. Гоголь не пише українською, припускаючи, що, вочевидь, М. Гоголь не володіє належним чином українською мовою, зауважуючи при цьому, що можливі й інші причини, але вголос називати їх не хотів, хоча дав жорстку, але чітку однослівну дефініцію гоголівському феномену — відступництво ${ }^{19}$. Але ж М. Гоголь, як і Т. Шевченко, не володів абсолютно досконало нормативною російською мовою, проте М. Гоголь, на відміну від Т. Шевченка, не володів й українською настільки, щоб досконало писати, та ще й прозу, стиль якої не був розроблений. Ось у чому трагедія — посередній рівень мовної і комунікативної компетенції М. Гоголя як української мовної особистості.

Не вважаючи термін „роздвоєння” коректним, усе ж погоджуємося із таким аргументованим твердженням С. Нахліка: "Якщо Шевченко... переживав мовно-культурне роздвоєння, а до глибини душі (але не повністю) русифікований Гоголь - національне"20. М. Гоголь - феномен ситуації, що могла виникнути лише в умовах тогочасного суспільства, ситуації, що склалася в контексті становлення української нації, розвитку української національної літературної мови. Усе ж М. Гоголь зумів явити світу українську ментальність, українську

${ }^{18}$ Там само, с. 277-278.

19 Див.: Ю. Барабаш, Мова імперї̈, [в:] „Урок української”, 2004, № 1, с. 56; Л. Мацько, Тарас Шевченко - основоположник нової української літературної мови, [в:] їі ж, Українська мова в освітньому просторі, Навч. посібник для студентів-філологів освітньо-кваліфікаційного рівня „магістр”, Київ 2009, с. 177-178.

${ }^{20} \mathrm{C}$. Нах лік, зазн. джерело, с. 282. 
культуру й фрагментарно українську мову, продемонструвавши, що це не наріччя. Він привернув увагу до України, як ніхто інший з українців, що писали виключно російською. М. Гоголь - реальний і геніальний продукт своєї епохи з усіма іiі суперечностями. Засуджувати його не можна, як не можна засуджувати й Т. Шевченка за те, що він опинився в Петербурзі, став митцем Російської імперії і писав не лише українською, але й частково російською. Ці факти треба розуміти в контексті епохи й ситуації. Говорити про „роздвоєність”, „дволикість”, „двоєдушшя” і под., засуджувати геніїв легко сьогодні, перебуваючи зовсім в іншому історико-політичному контексті.

Проте й сьогодні в Україні існують проблеми ті самі, хоч історикополітичний контекст інший. Геніїв треба сприймати такими, якими вони були. Вони найвиразніше відображають поступ нації. Зазначена проблема вже окреслена як проблема українського дуалізму (О. Забужко, С. Нахлік та деякі ін.), що, вочевидь, властива українському національному характеру.

Щоденник, як видається, репрезентує неповторну шевченкову стилістику, що має вияв у проекції на російську мову, а це демонструє закономірний факт - здатність бути двомовним в умовах Російської імперії, але відтворювати не російсько-український білінгвізм, а все ж українсько-російський.

Т. Шевченку вдалося репрезентувати живу атмосферу своєї епохи з усією іiі специфікою, завдяки використанню відповідних мовних засобів, відтворення української ментальності, а також репрезентуючи риси власного стилю - поєднання сатиричного з ліричним, інтимізованим, суб'єктивним.

Зробимо висновок і стосовно того, що ж спонукало Тараса Шевченка писати щоденник, відтворювати діалог Ego - Alter Ego чужою для діариста російською мовою? Відповідь ураховує комплекс причин: 1) русифікація мовного потоку свідомості письменника, зумовлена російськомовним солдатським побутом, психологічними чинниками, зумовленими наявністю російськомовного довкілля загалом, перепискою з друзями, що здійснювалася російською мовою, забороною писати по-українськи; 2) прагнення вдосконалити, покращити свою російськомовну комунікативну компетенцію, що дало би змогу краще писати художні твори російською, комфортно почувати себе в російськомовному середовищі; 3) відсутність в українській літературній мові розробленого стилю художньої прози, стилю епістолярного, публіцистичного, тому для його розробки потрібно було вправлятися; 4) переосмислення своєї свідомості, самоідентифікація наприкінці заслання, глибше розуміння свого Ego i Alter Ego: по-перше, як українця, українського патріота, носія української ментальності, українського національного характеру, українського національного поета, що сповідує українську національну ідею; Батьківщиною якого є Україна, але, по-друге, це й одночасне розуміння себе як загальноросійського громадянина, гуманіста, який лояльно сприймає культуру й мову Російської імпеpiï, де йому доводиться жити, працювати, спілкуватися з висококультурними особистостями, загалом існувати; розуміння контексту епохи й простору свого буття, того, що на даний момент він не може змінити, але того, до чого він повинен пристосуватися, не налаштувавшись на суперечку із власним Alter Ego, а перебуваючи із ним у відносній гармонії. Але це не слід називати роздвоєністю, бо це об'єктивне розуміння свого становища, з якого на той час не було іншого виходу. Т. Шевченко сприймав в Росії те, що було йому близьким, і заперечував те, що було йому зовсім чужим, хоча концептуальна опозиція “свій - чужий” набула у його свідомості, зокрема й мовній, широкого ракурсу. 